\title{
Chronology, Geochemistry and Geological Significance of Haizi Bimodal Intrusive Bodies in Wuding District, Central Yunnan
}

\author{
Bin Yang1, Weiqing Wang2, Guochen Dong2*, Yang Guo', Zizheng Wang1, Lin Hou² \\ ${ }^{1}$ Chengdu Center of China Geological Survey, Chengdu, China \\ ${ }^{2}$ Department of Geosciences and Resource, China University of Geosciences, Beijing, China \\ Email: ${ }^{316641491 @ q q . c o m}$
}

Received 26 March 2015; accepted 4 May 2015; published 8 May 2015

Copyright (C) 2015 by authors and Scientific Research Publishing Inc.

This work is licensed under the Creative Commons Attribution International License (CC BY). http://creativecommons.org/licenses/by/4.0/

(c) (i) Open Access

\section{Abstract}

The Haizi diabase-granite porphyry composite rock mass is located in the Wuding-Yanjing taphrogenic trough within the Paleoproterozoic Kangdian fault-uplift zone. According to field observations, the diabase is divided into two types: central facies and marginal facies; the granite porphyry directly contacts the central facies of diabase without transitional intermediate rock. In order to disclose its geological and petrological significances, this paper carried out the LA-ICP-MS zircon $\mathrm{U}-\mathrm{Pb}$ dating and geochemical investigation on both masses of Haizi diabase and granite porphyry. The results showed that the ${ }^{207} \mathrm{~Pb} /{ }^{206} \mathrm{~Pb}$ weighted average age of granite porphyry is $1764 \pm 18 \mathrm{Ma}$ and diabase $1765 \pm 5.4 \mathrm{Ma}$. The geochemical investigations revealed that the Haizi diabase is a kind of high-potassium alkaline basalt and the granite porphyry a kind of low-potassium rhyolite, both enriched with high field intensity elements and depleted in large-ion lithophile elements; there is obvious component intermittence between the diabase and the granite porphyry, both being bimodal and showing characteristics of continental rift valley magmatite. The in situ $\mathrm{Hf}$ isotope of dating zircon showed that mantle materials participated in the formation and emplacement of Haizi granite porphyry and crust materials participated in the formation of diabase. This meant that crustal remelting and accretion of new crust occurred in this region in the 1.7 Ga period. It can be therefore inferred that the Haizi bimodal intrusive rock came into being due to the breakup of Kunyang rift valley and rapid ascent of mantle materials in the 1.7 Ga period, which echoed the global Columbia supercontinent breakup and was the first petrological record of that breakup found at the southwest margin of Yangtze platform.

\section{Keywords}

Hai Zi, Bimodal Intrusions, Geochemistry and Geochronology, Geological Significance,

\footnotetext{
${ }^{*}$ Corresponding author.
}

How to cite this paper: Yang, B., Wang, W.Q., Dong, G.C., Guo, Y., Wang, Z.Z. and Hou, L. (2015) Chronology, Geochemistry and Geological Significance of Haizi Bimodal Intrusive Bodies in Wuding District, Central Yunnan. Open Journal of Geology, 5, 239-253. http://dx.doi.org/10.4236/ojg.2015.55022 


\section{Central Yunnan}

\section{Introduction}

In tectonic structure, the central Yunnan region is a portion of the Kangdian fault-uplift zone. The zone is a narrow belt following a south-north trend and in tectonic structure a Yangtze block (grade II) of the pan-Yangtze tectonic province (grade I), reaching Kangding, Sichuan in the north, Yanjing River and Dahong Mountain in Xinping County, Yunnan in the south, Pudu River rift and Xiaojiang River rift in the east and Lyuzhi River rift in Yuanmou County, Yunnan. The region has extremely developed structure and magmatism after a long geological evolution starting from the Early Proterozoic and therefore was made as a research focus by lots of domestic and foreign scholars who published many papers on its magmatism chronology and paleo-continent reconstruction: $\mathrm{Li}$, et al. [1] believed according to their research findings that Yangtze craton might be a block fragment of the supercontinent Rodinia spliced by the Australia and South Pole blocks in the early stage of Mesoproterozoic $(1.0 \mathrm{Ga})$; Fitzsimons [2] also believed according to his research on the zircon chronology of the South Pole block during the Grenville orogenic period of Southern China that the splicing time of Rodinia was between $1400 \mathrm{Ma}$ and $900 \mathrm{Ma}$; Li, et al. [3] limited the occurrence time of Grenville orogeny to be between 1.3 Ga and 1.0 Ga; Yan et al. [4] discussed the location of Southern China in the paleo-continent Rodinia; Wang et al. [5] discussed the response of Kangdian axis to the Rodinia event. According to all research findings mentioned above, it can be believed that the central Yunnan region surely underwent a period of tectonic movement around $1.0 \mathrm{Ga}$ that falls into the global Grenville orogenic period and can reflect the convergence and breakup of the supercontinent Rodinia.

However, the research on the supercontinent Columbia (around 1.8 Ga) before the supercontinent Rodinia in the central Yunnan region (the southwest fringe of Yangtze platform) so far has yielded few published findings but some theoretical speculations and explanations due to the limitations of objective conditions (geological changes, weathering and denudation) so that there are no great evidences [6], especially those magmatism ones. As the discovered Haizi granite porphyry-diabase in Wuding region is the first bimodal intrusive rock at around 1.7 Ga identified at the southwestern fringe of the Yangtze platform, this paper intends to supplement the absent magmatism information of the central Yunnan region in a period from 1.8 Ga to 1.6 Ga and also provide some bases for the researches on the tectonic evolution of this region at $1.7 \mathrm{Ga}$ and the global supercontinent Columbia breakup through the research on the bimodal intrusive rock.

\section{Geological Background}

In 1945, Mr. Huang Jiqing initially created a concept "Kangdian axis” for the central Yunnan region; in 1981, Ren Jishun elaborated that the Kangdian axis is a secondary tectonic element of the western fringe of the Yangtze platform from the perspective of polycyclic oogenesis. Since 1980s, many scholars successively made their elaborations of this region using the theory of plate tectonics: Luo [7] put forward that the Kangdian axis was an island arc zone in the Mesoproterozoic, which went through the occurrence, development and extinction of continental rift valley of the post-platform stage from the Neopaleozoic to the Mesozoic and was known as Panzhihua-Xichang paleo-rift valley zone; Hua [8] believed that the tectonic environment of the Kunyang group is a paleo-continent rift valley-aulacogen environment and suggested that the rift valley movement occurred in the Mesoproterozoic and its products be named Kunyang aulacogen; Gong et al. [9] believed that the Kangdian axis is the marginal rift valley of the Yangtze paleo-continent and named it Kunyang paleo-intercontinental rift valley (Kunyang rift valley for short).

The Kunyang rift valley is clammed between Anning River-Yuanmou-Lyuzhi River rift and Xiaojiang rift; its basal structure is of EW or NEE trend; the rift valley period (Dongchuan Group) structure is of SN trend, in particular, the first-grade structure of the rift valley zone is a deep and large rift controlling the overall shape of the rift valley, stratum space distribution, volcanic activity and building magma metallogenic belt that has a SN edge rift and parallel inside the rift valley. The second-grade structure in the rift valley zone came into being in the course of regional squeezing action occurred in the middle and late periods of the rift valley's development and closed period, mainly consisting of SN and EW groups of rifts, which often is accompanied by folding 
tectonics. The roles of the second-grade fault structure makes the tectonic pattern with mutually intersected horst and graben inside the Kunyang rift valley more complex so as to form five rift-subsidence basins in the HuiliDongchuan and Wuding-Yuanjiang River taphrogenic troughs: Dongchuan, Bijia Mountain, Wuding, Yimen and Yuanjiang River (Figure 1(a)). The Haizi composite rock mass in the present study is located in the Wuding rift-subsidence basin.

The Haizi rock mass is located 200 - $4600 \mathrm{~m}$ to the north of Xinchangchong village office in Wuding County, being a part of the north segment of the Wuding-Yuanjiang River taphrogenic trough located in the middle-bysouth portion of the Kangdian fault uplift zone in tectonic structure. The rift in that area is of Haizi-Degu old regional rift; the structure in the area became complex due to the occurrence of NW and EW cross faults in late period. The strata emerged in the area are mainly Paleoproterozoic-Mesoproterozoic Dongchuan Group strata; the Paleoproterozoic strata include Pingdingshan Group $\left(\mathrm{Pt}_{1} p\right)$, Yinmin Group $\left(\mathrm{Pt}_{1} y\right)$ and Luoxue Group $\left(\mathrm{Pt}_{1} l\right)$; the Mesoproterozoic strata is Etouchang Group $\left(\mathrm{Pt}_{2} e\right)$. The magmatism in that area is better developed, belonging to granite porphyry and diabase (Figure $1(b))$.

\section{Geological and Petrological Characteristics of Rock Mass}

Granite porphyry appears at two locations in the area, its total emerged area reaching about $0.49 \mathrm{~km}^{2}$, being main emerged magmatism type. The rock mass as a whole is nearly in a circular shape, its edges looking like bay, the mineral facies at its center and edges varying little, the granularity of authigenic mineral not changing significantly. The granite porphyry and the gabbrocliabase of the Yinmin Group, Luoxue Group and periphery are in an intrusive contact relationship. The sampled rock mass this time is a largest and freshest granite porphyry emerged in the area, its area reaching $0.35 \mathrm{~km}^{2}$.

The weathering surface of the hand specimen granite porphyry is hoary (Figure 2(a)), the fresh surface flesh-red, with a dense block like tectonics and porphyritic structure. The fresh portion is hard and breaks along

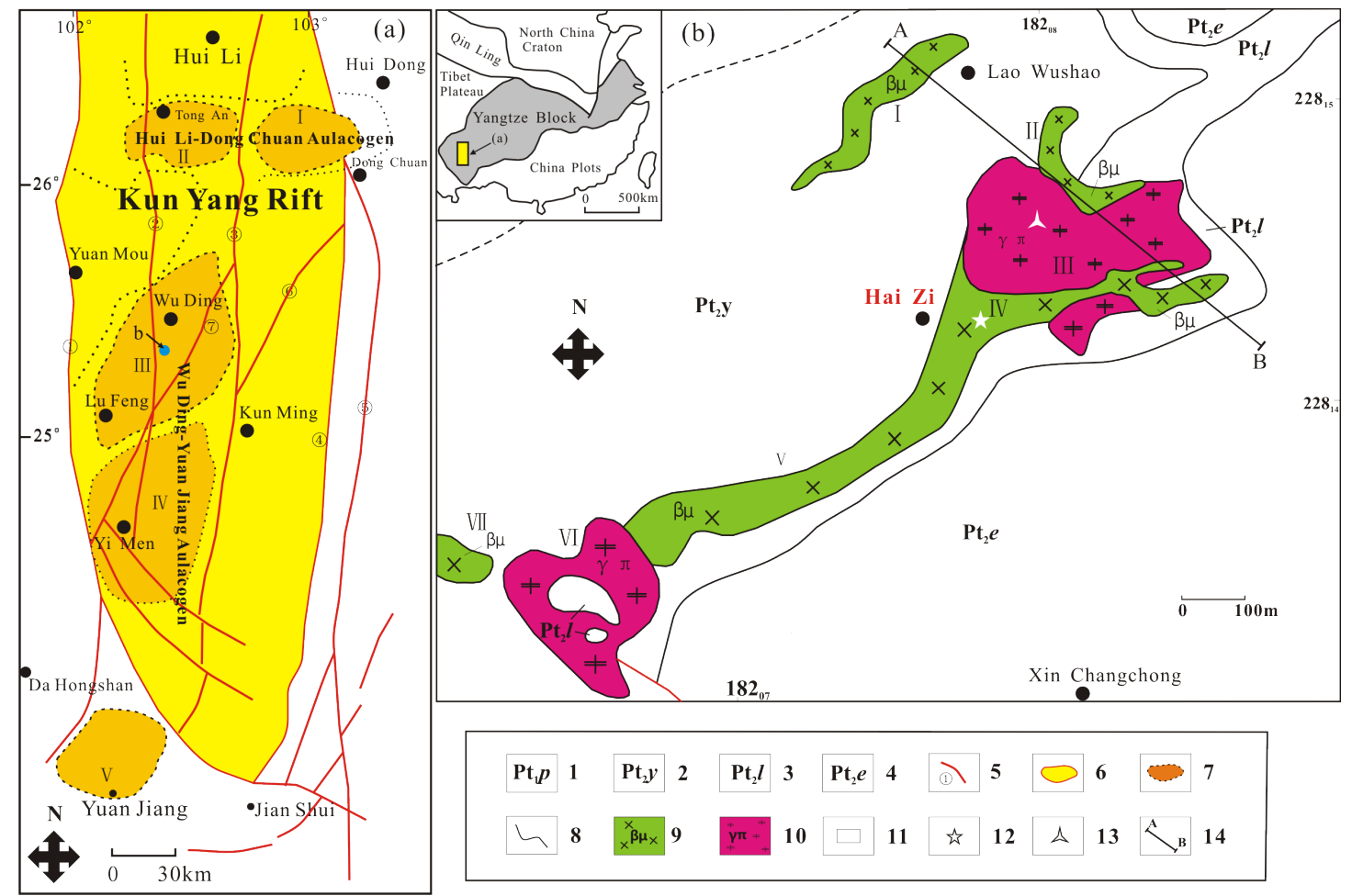

Figure 1. Sketch map of the Hai Zi in Wu Ding district 1-Ping Dingshan Group; 2-Yin Ming Group; 3-Luo Xue Group; 4-E Touchang Group; 5-Regional faults number; 6-Koya Rift; 7-Rift basin; 8-Geological boundary; 9-Diabase; 10-Granite porphyry; 11-Scope of the study area; 12-Sampling Location; 13- Section: Figure 3; (b) I -Dong Chuan Rift Basin; II -Beacon Hill Rift Basin; III-Wu Ding Rift Basin; IV-Yi Men Rift Basin; V-Yuan Jiang Rift Basin; Regional faults number: (1) Yuan Mou-Lv Zhijiang fault; (2) Tang Lang-Yi Men fault; (3) Pudu river fault; (4), (5) Xiao Jiang fault: I, II, III, IV-Rock Number. 


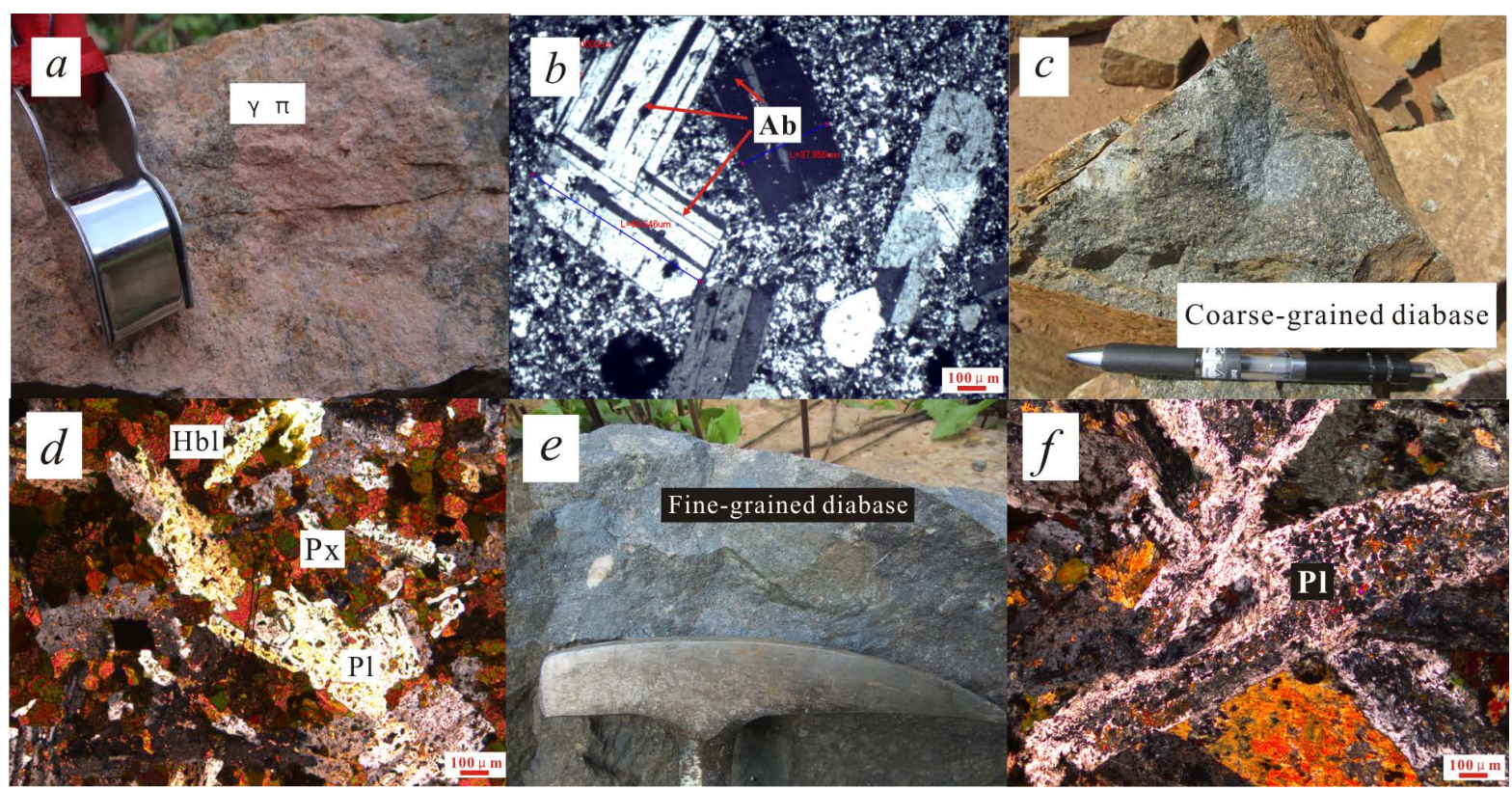

Figure 2. Petrographic Photo of Hai Zi Bimodal Intrusive rocks in Wu Ding district Ab: Albite, Mt: Magnetite, Q: Quartz, Pl: Plagioclase, Px: Pyroxene, Bi: Biotite, Hbl: Amphibole; a:granite porphyry (Unweather); (b) Albite phenocrysts (Polysynthetic twins); (c) Coarse-grained diabase; (d) Microscopic photos for diabase, Albites and Pyroxenes were altered; (e) Finegrained diabase; (f) Microscopic photos for Fine-grained diabase.

the jointer plane if it is knocked. The microscopic observation shows that it mainly consists of quartz and albite. Phanerocryst is albite, mainly fine middle granules with a little rough grains (Figure 2(b)). The matrix is composed of quartz, a little sericite and chlorite. Metallic mineral contained in the porphyry are mainly magnetite which is in fine granule and partially evenly dispersed; some aggregates are of irregular small lumps unevenly distributed.

The periphery of granite porphyry is diabase with an emerged area in the study zone of $0.24 \mathrm{~km}^{2}$. The rock mass is laminated and stratoid bedding output. Due to its intrusive contact relationship with the Yinmin Group $\left(\mathrm{Pt}_{1} y\right)$ and Luoxue Group $\left(\mathrm{Pt}_{1} l\right)$. The diabase can be divided into central facies and marginal facies by the degree of mineral crystallization. The intermediate facies diabase hand specimen is of dark green, middle-rough granular structure, gabbro-diabasic structure, dense block like tectonics (Figure 2(c)). The rock is mainly composed of anorthose, augite, biotite and hornblende as well as a little magnetite. The anorthose is sheet-pile and columnar, with a granularity of $8-12 \mathrm{~mm}$. Some anorthoses are wrapped by hornblende crystal, representing an obvious crystal-anorthose structure. The dark mineral is mainly consisting of hornblende and a little augite. The hornblende is columnar and granular, the size equivalent to anorthose, mostly having undergone the uralitization, and the pleochroism being not visible. A part of augite has been intersected by carbonate, being xenomorphic granular, the size being $1 \mathrm{~mm}$ or so (Figure 2(d)).

The diabase of the marginal facies is grey green; compared to the central facies, the green hue becomes light while the grey hue becomes intense; it has a gabbro-diabase structure and dense blocklike tectonics (Figure 2(e)). The microscopic observation shows that its mineral association is identical with the central facies, but the authigenic mineral's granularity and the integrity of mineral crystal are different from the central facies, in particular, the anorthose mostly is automorphic columnar, rarely with polysynthetic twin and carlsbad twin. The porphyritic anorthose is columnar, having a granularity of $2.5-3.5 \mathrm{~mm}$. The matrix anorthose has a granularity of $0.5-1.2 \mathrm{~mm}$, the hornblende being reddish-brown and having pleochroism, the granularity of $0.5-1.2 \mathrm{~mm}$ (Figure 2(f)).

Granite porphyry and diabase are accompanied (Figure 3(a)) at their occurrence spots, directly contacted with the edges of diabase; the contact position is straight and level, extended far; their acidic portion and basic portion have totally different contact edges (Figure 3(b) and Figure 3(c)). According to their contact relationship and field observation results, it's preliminarily inferred that the era of granite porphyry should be same as or slightly later than diabase. 

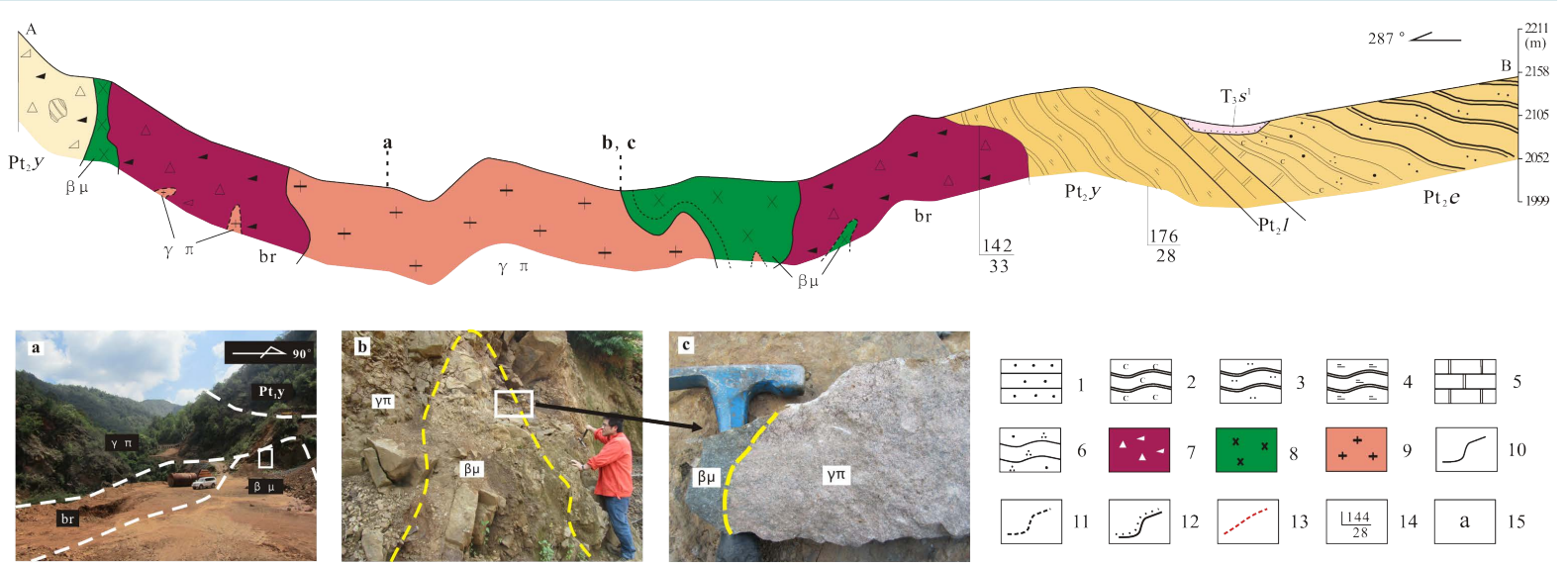

Figure 3. Profile of Hai Zi Bimodal Intrusive rocks in Wu Ding district (Measured, 2011) 1: Sandstone; 2: Carbonaceous slate; 3: Silty slate; 4: Sericite slate; 5: Dolomite; 6: Metamorphic quartz sandstone; 7: Breccia; 8: Diabase; 9: Granite porphyry; 10: Geological boundary (Measured); 11: Geological boundary (Speculate); 12: Angular unconformity; 13: Fault; 14: Occurrence; 15: Photo; $\mathrm{T}_{3} s^{1}$ : She Zi Group; $\mathrm{Pt}_{2} e$ : E Touchang Group; $\mathrm{Pt}_{2} l$ : Luo Xue Group; $\mathrm{Pt}_{2} y^{2}$ : Yin Ming Group Sec; $\mathrm{Pt}_{2} y^{3}$ : Yin Ming Group Third; $\beta \mu$ : diabase; $\gamma \pi$ : Granite porphyry; br: Breccia, Ab: Albite, Pl: Plagioclase, Px: Pyroxene, Bi: Biotite, Hbl: Amphibole.

\section{U-Pb Chronological Characteristics of Zircon}

The formation era of magmatism has always been the focus of magmatite researches. The present research focuses on the zircon chronology of two end members of Haizi composite rock, respectively collected fresh granite porphyry and diabase for choosing zircon monomineral. See Figure 1 for the sampling spots. The selection and target preparation of zircon was done in the key national laboratory of geological process and mineral resources of China University of Geosciences (Wuhan). The cathodoluminescence photography and dating experiment of zircon was done in the key laboratory of the Mineral Resources Institute of the Chinese Academy of Geological Sciences. See HouKejun, et al. [10] for the experiment procedures and treatment methods.

The zircon of Haizi granite porphyry is mainly of long column shape, large grains, broken parts mostly greater than $100 \mu \mathrm{m}$. The zircon in diabase mainly is hexagonal dipyramid, the plane of section is quadrangle or pentagon, the grain mostly less than $100 \mu \mathrm{m}$. All in all, the zircon of both kinds of rocks has clear edges and corners of crystal form without ground rounded corners and metamorphic edges. The zircon CL images of both kinds of rock mass are dark; the shock ring zone of the zircon in diabase is relatively wide, both having a high $\mathrm{Th} / \mathrm{U}$ ratio $(>0.4)$, so from the perspective of either the crystal shape or $\mathrm{Th} / \mathrm{U}$ ratio, the zircon in Haizi diabase-granite porphyry is virgin magmatic zircon (Figure 4(a) and Figure 4(b)).

See Table 1 for the zircon LA-ICP-MS analysis results of Haizi diabase -granite porphyry. As the dating results are greater than $1.0 \mathrm{Ga}$, the ${ }^{207} \mathrm{~Pb} /{ }^{206} \mathrm{~Pb}$ weighted average age of zircon is used as the age of the rock mass. According to the experiment results, the ${ }^{207} \mathrm{~Pb} /{ }^{206} \mathrm{~Pb}$ weighted average age of granite porphyry is $1764 \pm 18 \mathrm{Ma}$ $(\mathrm{MSWD}=0.3)($ Figure $5(\mathrm{a}))$; the ${ }^{207} \mathrm{~Pb} /{ }^{235} \mathrm{U}$ weighted average age of diabase is $1765.0 \pm 5.4 \mathrm{Ma}(\mathrm{MSWD}=$ 0.46) (Figure 5(b)).

\section{Petrogeochemistry}

Of the samples used in the test, the granite porphyry is from the rock mass IV, the diabase is from the rock masses II and III (Figure 1(b)). The collecting of samples avoided those places with alteration, mineralization and weathering. The samples used to test major trace rarely earth were removed of skin when they are made into powder. The central fresh portion was crashed into a state below 200 meshes in a pollution-free way. The major trace and rare earth tests were all done in the Beijing Research Institute of Uranium Geology. The major quantity tester is AB104-L, PW2404 X-ray fluorescence spectrometer. The detection bases include GB/T14506. 142010 Method for Chemical Analysis of Silicate Rock Part 14: Determination of Ferrous Oxide Content, GB/T14506.28-2010 Method for Chemical Analysis of Silicate Rock Part 28: Determination of 16 Major and Secondary Components Contents. The testing temperature is $20^{\circ} \mathrm{C}$, and the relative humidity $30 \%$. The trace rare earth tester is ELEMENT plasma mass spectrometry. The detection basis is DZ/T0223-2001 General Rules for 


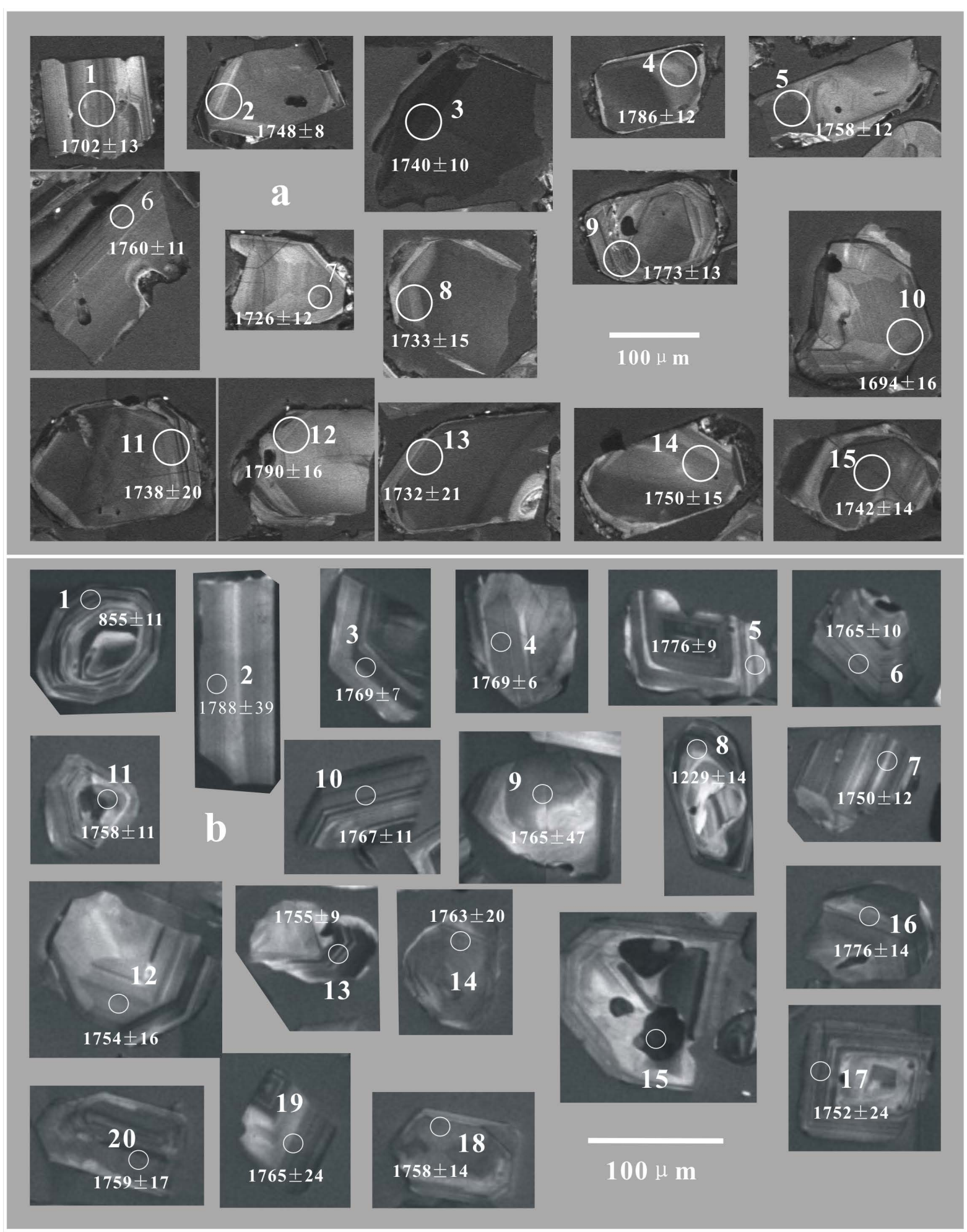

Figure 4. CL photos of zircons from Hai Zi Bimodal Intrusive rocks (a) Granite porphyry; (b) Diabase 3 U-Pb Chronological characteristics of zircon.

Inductively Coupled Plasma Mass Spectrometric Analysis. The testing temperature is $20^{\circ} \mathrm{C}$ and the relative humidity is $30 \%$. 


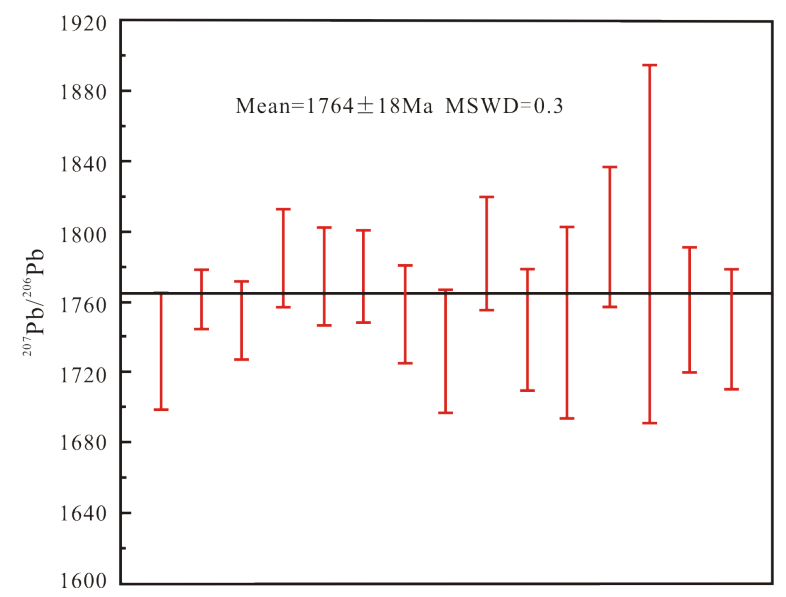

(a)

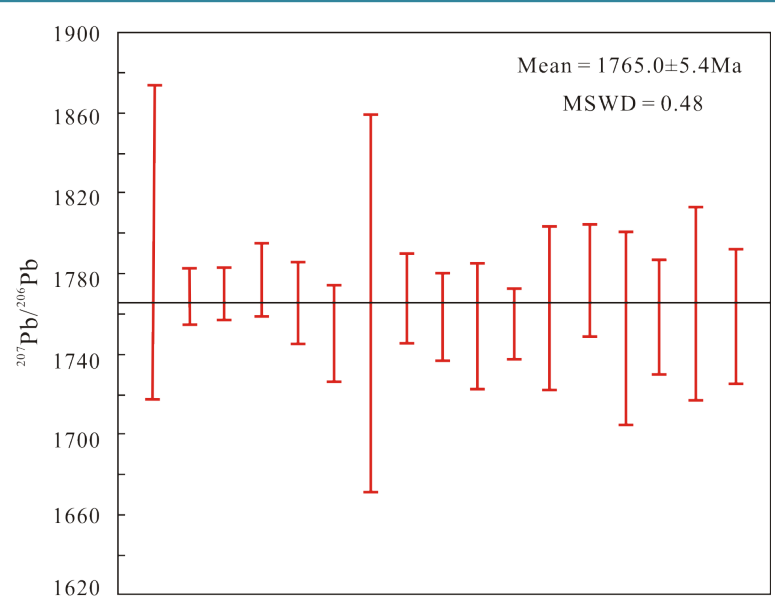

(b)

Figure 5. Weighted average data of the zircons U-Pb for Hai Zi bimodal intrusive rocks: (a) ${ }^{207} \mathrm{~Pb} /{ }^{206} \mathrm{~Pb}$ Weighted average age for Granite porphyry; (b) ${ }^{207} \mathrm{~Pb} /{ }^{206} \mathrm{~Pb}$ Weighted average age for Diabase.

Table 1. LA-ICPMS analyzed data of the Zircons U-Pbfor Hai Zi Bimodal Intrusive rocks.

\begin{tabular}{|c|c|c|c|c|c|c|c|c|c|c|c|c|c|c|}
\hline & \multirow[b]{2}{*}{$\mathrm{NO}$} & \multicolumn{6}{|c|}{ Isotope ratio } & \multicolumn{6}{|c|}{ Age (Ma) } & \multirow[b]{2}{*}{${ }^{-232} \mathrm{Th} /{ }^{238} \mathrm{U}$} \\
\hline & & ${ }^{207} \mathrm{~Pb} /{ }^{206} \mathrm{~Pb}$ & $1 \sigma$ & ${ }^{207} \mathrm{~Pb} /{ }^{235} \mathrm{U}$ & $1 \sigma$ & ${ }^{206} \mathrm{~Pb} /{ }^{238} \mathrm{U}$ & $1 \sigma$ & ${ }^{207} \mathrm{~Pb} /{ }^{206} \mathrm{~Pb}$ & $1 \sigma$ & ${ }^{207} \mathrm{~Pb} /{ }^{235} \mathrm{U}$ & $1 \sigma$ & ${ }^{206} \mathrm{~Pb} /{ }^{238} \mathrm{U}$ & $1 \sigma$ & \\
\hline \multirow{8}{*}{$\begin{array}{l}\text { Granite } \\
\text { porphyry }\end{array}$} & 1 & 0.1057 & 0.0019 & 4.3456 & 0.0700 & 0.2983 & 0.0027 & 1727 & 17 & 1702 & 13 & 1683 & 14 & 0.88 \\
\hline & 3 & 0.1067 & 0.0015 & 4.5464 & 0.0547 & 0.3092 & 0.0025 & 1744 & 11 & 1740 & 10 & 1737 & 12 & 0.90 \\
\hline & 5 & 0.1102 & 0.0018 & 4.6511 & 0.0660 & 0.3063 & 0.0027 & 1802 & 14 & 1758 & 12 & 1723 & 13 & 0.79 \\
\hline & 7 & 0.1072 & 0.0017 & 4.4756 & 0.0645 & 0.3027 & 0.0026 & 1753 & 14 & 1726 & 12 & 1705 & 13 & 0.78 \\
\hline & 9 & 0.1091 & 0.0018 & 4.7315 & 0.0717 & 0.3145 & 0.0028 & 1785 & 15 & 1773 & 13 & 1763 & 14 & 0.78 \\
\hline & 11 & 0.1070 & 0.0027 & 4.5364 & 0.1084 & 0.3075 & 0.0036 & 1748 & 27 & 1738 & 20 & 1728 & 18 & 0.68 \\
\hline & 13 & 0.1133 & 0.0020 & 4.6802 & 0.0742 & 0.2996 & 0.0028 & 1793 & 51 & 1732 & 21 & 1682 & 15 & 0.91 \\
\hline & 15 & 0.1050 & 0.0019 & 4.5582 & 0.0751 & 0.3145 & 0.0030 & 1714 & 17 & 1742 & 14 & 1763 & 14 & 0.89 \\
\hline \multirow{9}{*}{ Diabase } & 2 & 0.109 & 0.002 & 4.372 & 0.103 & 0.290 & 0.002 & 1788 & 39 & 1707 & 19 & 1642 & 11 & 1.139 \\
\hline & 4 & 0.108 & 0.000 & 4.367 & 0.027 & 0.293 & 0.002 & 1769 & 6 & 1706 & 5 & 1658 & 8 & 1.213 \\
\hline & 6 & 0.108 & 0.001 & 4.293 & 0.041 & 0.289 & 0.002 & 1765 & 10 & 1692 & 8 & 1635 & 10 & 0.936 \\
\hline & 10 & 0.107 & 0.001 & 4.416 & 0.053 & 0.298 & 0.003 & 1767 & 11 & 1715 & 10 & 1681 & 14 & 1.405 \\
\hline & 12 & 0.107 & 0.001 & 4.365 & 0.073 & 0.295 & 0.004 & 1754 & 16 & 1706 & 14 & 1667 & 22 & 0.973 \\
\hline & 14 & 0.108 & 0.001 & 4.632 & 0.120 & 0.312 & 0.008 & 1763 & 20 & 1755 & 22 & 1749 & 38 & 1.088 \\
\hline & 16 & 0.109 & 0.001 & 4.496 & 0.060 & 0.300 & 0.004 & 1776 & 14 & 1730 & 11 & 1693 & 18 & 0.906 \\
\hline & 18 & 0.108 & 0.001 & 4.433 & 0.067 & 0.299 & 0.004 & 1758 & 14 & 1718 & 12 & 1686 & 19 & 1.034 \\
\hline & 20 & 0.108 & 0.001 & 3.899 & 0.055 & 0.263 & 0.003 & 1759 & 17 & 1613 & 11 & 1505 & 17 & 1.295 \\
\hline
\end{tabular}

Remark: $1 \sigma$ for Isotope ratio error is Absolute error, $1 \sigma$ for Age error is Relative error, the statistics of Granite porphyry are come from [11].

\subsection{Characteristics of Major Elements}

See Table 2 for the testing results of the major elements of Haizi diabase-granite porphyry. In the TAS illustration (Figure 6(a)), the cultellation of diabase fell in the feldspathoid gabbro, while that of granite porphyry fell between granodiorite and granite. The rock classification of $\mathrm{SiO}_{2}$ and $\mathrm{K}_{2} \mathrm{O}$ (Figure 6(b)) revealed that the Haizi diabase is of high-potassium alkali basalt while the granite porphyry is of low-potassium rhyolite. The calculation of the geochemical parameters of the main components also revealed that the $\sigma$ mean (1.28) of granite porphyry differs greatly from the diabase (15.3). In alkali content, the granite porphyry (6.03) is slightly less than 


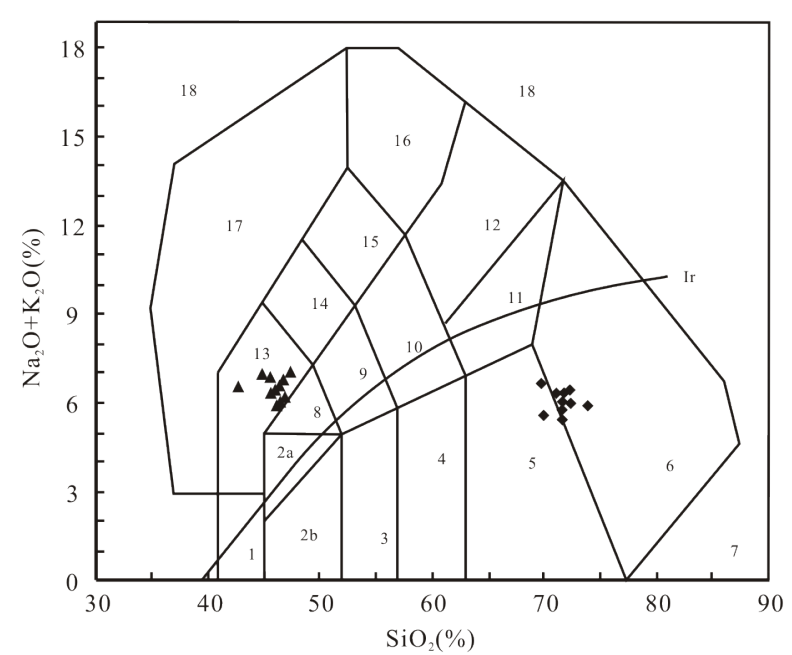

(a)

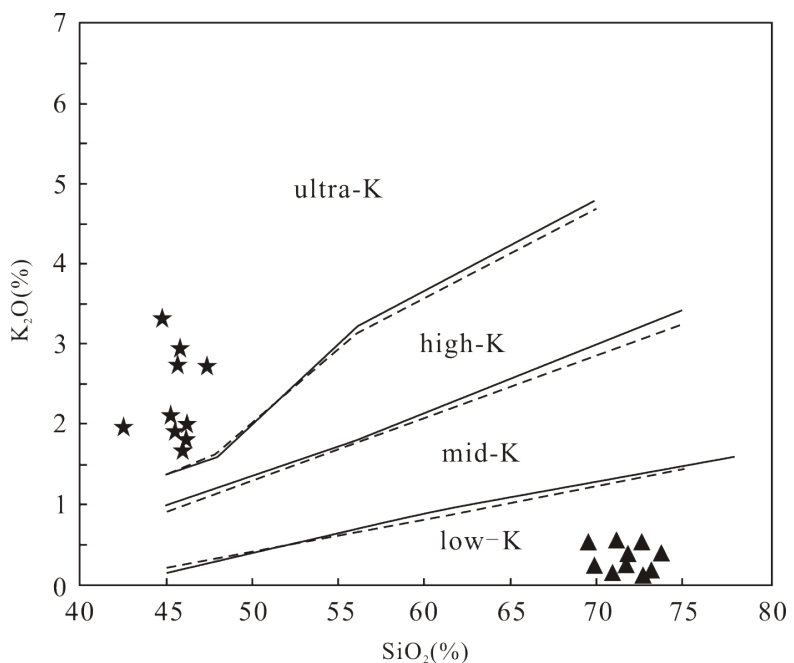

(b)

Figure 6. Classification for Hai Zi bimodal intrusive rocks in Wu Ding a:TAS Diagram, Diabase-Triangle; Granite porphyry-Square; Ir: Irvine; 1: Olivine gabbro; 2a: Alkaline gabbro; 2b: Sub-alkalinegabbro; 3: Gabbro-diorite; 4: Diorite; 5: Granodiorite; 6: Granite; 7: SiliconBritish rock; 8: Two gabbro; 9: Two diorite; 10: Monzonite; 11: Quartz monzonite; 12: Syenite; 13: Vice-feldspar gabbro; 14: Vice-feldspar two diorite; 15: Vice-feldspar syenitemonzonite; 16: Vice-feldspar syenite; 17: Vice-length plutonic; 18: Crude leucite rocks; $\mathrm{B}$ : $\mathrm{SiO}_{2}-\mathrm{K}_{2} \mathrm{O}$ diagram, Five-pointed star-Diabase; Triangle-Granite porphyry; The Dashed comes from [12] and the solid line comes from [13].

the diabase (6.614). According to the TAS illustrations, rock series and geochemical parameters, the Haizi diabase should be of parlkaline diabase, while the accompanied granite porphyry should be of calc alkali granite.

\subsection{Characteristics of Trace Elements of Rare Earth}

In the standard minor elements spider diagram of original mantle of minor elements (Figure 7(a)), the standard curve shows the following features: 1) the curve of granite porphyry is nearly horizontal without obvious right or left tilting trend; the curve of diabase shows right tilting trend; 2) the relatively enriched elements of granite porphyry include Rb, Th, U, Zr and Hf; the relatively depleted elements include $\mathrm{Ba}, \mathrm{K}, \mathrm{Sr}, \mathrm{P}$ and Ti; the relatively enriched elements of diabase include $\mathrm{Rb}, \mathrm{La}, \mathrm{Nd}, \mathrm{Zr}$ and $\mathrm{Hf}$; the relatively depleted elements include $\mathrm{Ba}$, Th, Sr and Ti. All in all, both are enriched with high field intensity elements ( $\mathrm{Zr}$ and $\mathrm{Hf}$ ), relatively depleted of large ion lithophile elements (Ba, Sr, $\mathrm{K}$ and $\mathrm{Ti}$ ); 3) Th and $\mathrm{U}$ are depleted in diabase but enriched in granite porphyry.

According to the rare earth elements analysis results of the Haizi composite rock mass (Table 2), the granite porphyry has higher $\Sigma$ REE, LREE and HREE than the diabase (Figure 7(b)). $\Sigma$ REE $=390.7 \times 10^{-6}-502.87 \times$ $10^{-6}$, averaged $463.32 \times 10^{-6}$, where LREE $=255.18 \times 10^{-6}-388.38 \times 10^{-6}$, HREE $=135.52 \times 10^{-6}-183.34 \times$ $10^{-6}$, LREE/HREE $=1.74-2.37 ;(\mathrm{La} / \mathrm{Yb}) \mathrm{n}=2.83-5.05,(\mathrm{La} / \mathrm{Sm}) \mathrm{n}=2.37-2.89 ; \delta \mathrm{Eu}=0.63-0.71$, averaged 0.66 . The total quantity of rare earth elements didn't change a lot; the light and heavy rare earth are clearly differential; the light rare earth is obviously enriched and has obvious negative Eu abnormality $(\delta \mathrm{Eu}=0.66)$, possibly indicating the fractional crystallization action of acidic anorthose in the course of the magmatism [16]. The diabase's $\Sigma$ REE $=193.51 \times 10^{-6}-322.58 \times 10^{-6}$, averaged $256.78 \times 10^{-6}, \mathrm{LREE}=128.16 \times 10^{-6}-228.68 \times 10^{-6}$, HREE $=65.35 \times 10^{-6}-117.36 \times 10^{-6}$, LREE/ HREE = $1.75-2.63 ;(\mathrm{La} / \mathrm{Yb}) \mathrm{n}=4.1-6.77,(\mathrm{La} / \mathrm{Sm}) \mathrm{n}=1.36-$ 2.55; $\delta \mathrm{Eu}=0.81-1.1$, averaged 0.92; the distributed curve collection (Figure 7(b)) has more obvious right tilting trend, basically increasing with the atomic number, the contents of rare earth elements gradually decreasing, therefore in the rare earth elements of diabase, the light and heavy rare earth has more obvious differentiation than granite porphyry.

\subsection{Zircon Hf Isotope Characteristics}

Zircon Hf isotope value contains abundant geological information. In this paper, the dated zircon in D1205 and D1438 was given in situ Hf isotope analysis. There are 15 testing points of granite porphyry and 17 ones of 
Table 2. Geochemistry compositions of Hai Zi Bimodal Intrusive rocks.

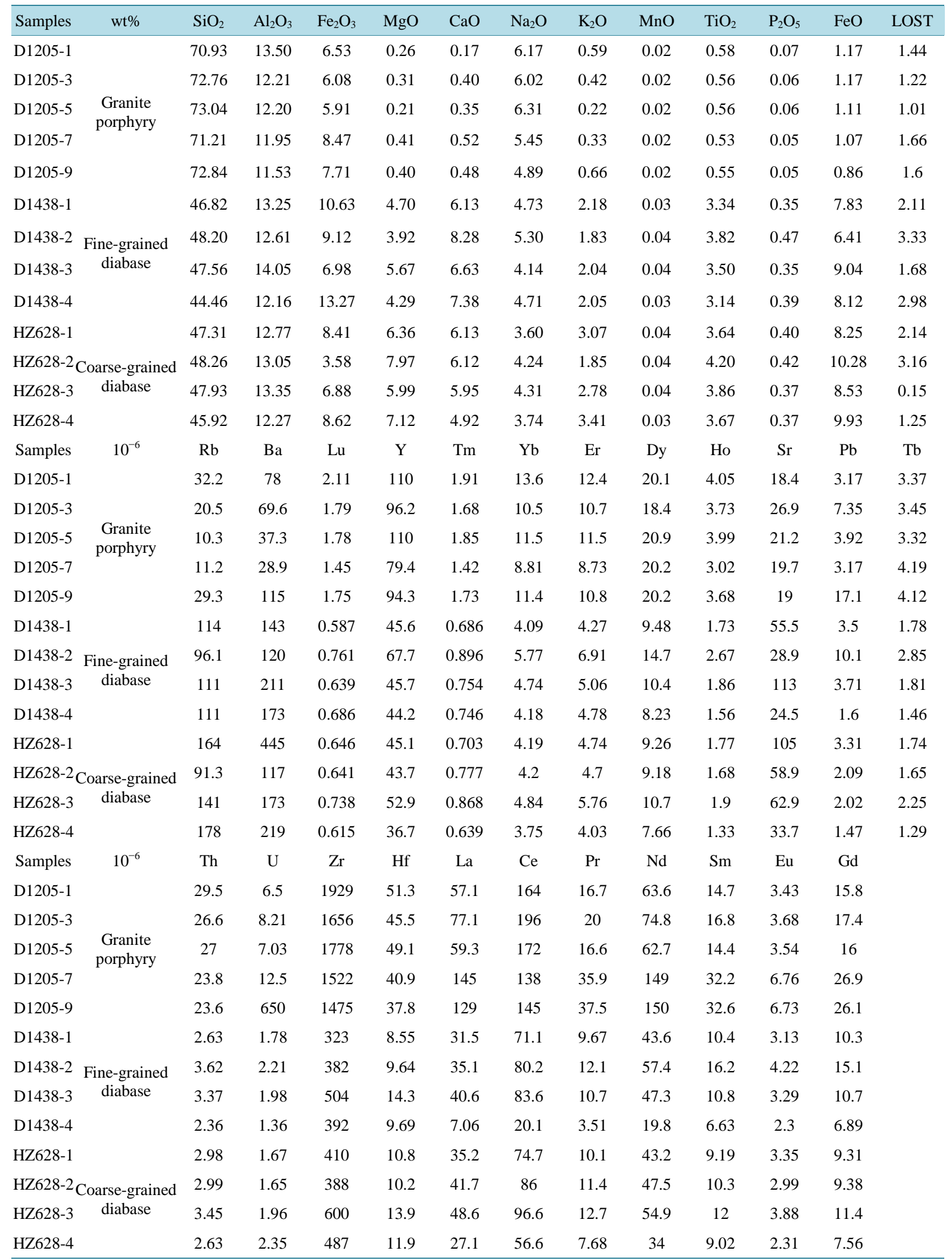

Remark: The statistics of D1205-1, D1205-3, D1205-5, D1205-7 and D1205-9 are come from [11]. 


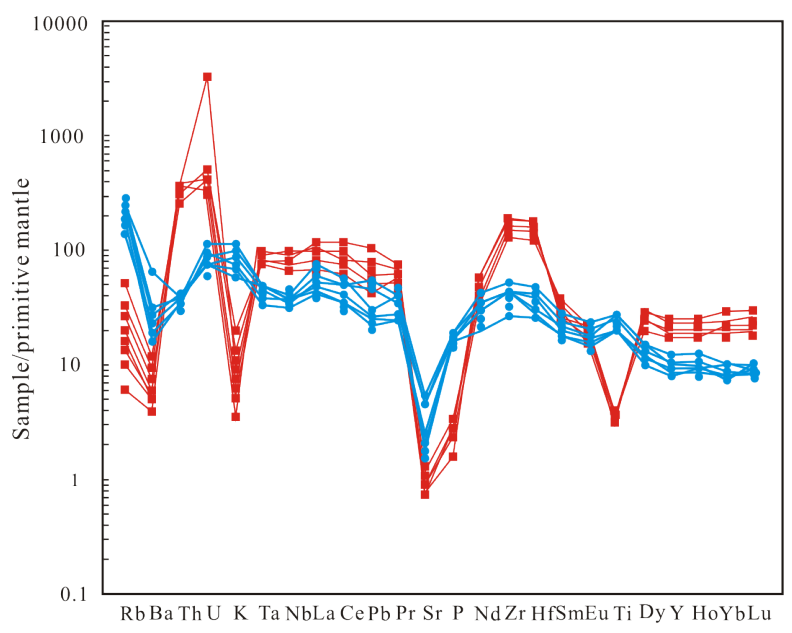

(a)

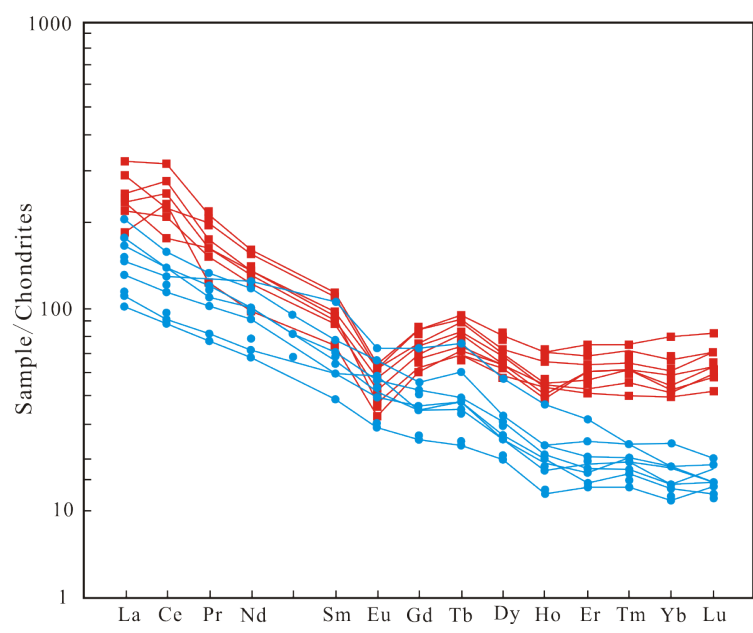

(b)

Figure 7. Primitive mantle-normalized REE and extended trace element and chondrite-normalized REE diagrams for Hai Zi bimodal intrusive rocks in WuDing. Normalization values and data for Trace elements from [14]; Normalization values and data forREE from [15]; Granite porphyry-Red Square, Diabase-Blue Round.

diabase. The testing point location is the same as the zircon $\mathrm{U}-\mathrm{Pb}$ dating point. According to the testing results, the ${ }^{176} \mathrm{Lu} /{ }^{177} \mathrm{Hf}$ of granite porphyry varies from 0.000578 to 0.002664 , averaged 0.001207 ; the ${ }^{176} \mathrm{Lu} /{ }^{177} \mathrm{Hf}$ of diabase varies from 0.000563 to 0.002477 , averaged 0.001359 (Table 3). The 的 $^{176} \mathrm{Lu} /{ }^{177} \mathrm{Hf}$ of both diabase and granite porphyry is less than 0.002 , indicating that these zircons have only a little radiation cause Hf accumulated. The measured ${ }^{176} \mathrm{Lu} /{ }^{177} \mathrm{Hf}$ can represent the Hf isotope composition of the magmatic system of zircon crystallization [17].

The composition of the HF isotope of the Haizi granite porphyry is simple, $\left({ }^{176} \mathrm{Hf} /{ }^{177} \mathrm{Hf}\right)_{\mathrm{t}}$ is mainly distributed in the range from 0.281660 to 0.281793 (Figure 8(a)); the $\varepsilon_{\mathrm{Hf}}(t)$ value mostly is between 0.1354 and 5.6758 (Figure 8(b)); there are two negative $\varepsilon_{\mathrm{Hf}}(t)$ values (D1205-1 and D1205-14), indicating that the Haizi granite porphyry is influenced by the mantle source substance and that mantle substance joined in the course of its formation and emplacement; its source area shell Hf isotope mode age $t_{\mathrm{DM}}{ }^{\mathrm{c}}=2070-2446 \mathrm{Ma}$. The $\left({ }^{176} \mathrm{Hf} /{ }^{177} \mathrm{Hf}\right)_{\mathrm{t}}$ in the diabase is mainly distributed in the range from 0.281567 to 0.281737 (Figure $8(\mathrm{a})$ ), $\varepsilon_{\mathrm{Hf}}(t)$ mostly negative, having 4 positive values. The negative value is distributed between -6.928776 and -0.617262 ; the positive value is distributed between 0.877603 and 1.428924, showing complicated rock formation cause information (Figure 8(b)). The single-stage model age is between 2081 and $2317 \mathrm{Ma}$; the second-stage mode age is between 2302 and 2662 Ma.

Wu et al. [17] think that the tracing of relevant Hf isotope, $t_{\mathrm{DM}}{ }^{\mathrm{c}}$ age can better reflect the average retention age of source district substance in the shell. If the model age of basalts is near its actual age, that means it comes from depleted mantle; otherwise, it may be mixed with the shell or come from the enriched mantle; while the model age of the granite mostly is greater than the formation age. The Haizi granite porphyry $t_{\mathrm{DM}}{ }^{\mathrm{c}}=2070-2446$ Ma, the diabase $t_{\mathrm{DM}}{ }^{\mathrm{c}}=2302-2662 \mathrm{Ma}$, its second-stage model age is greater than the actual age. Therefore, the Haizi diabase may be mixed with the shell substance in the course of its formation, possibly indicating that the mantle substance rapidly surged up at $1.7 \mathrm{Ga}$; while the lithogenous material of granite porphyry was obviously influenced by mantle source substance, indicating that some of the lithogenous material of granite porphyry came from diabase.

\section{Discussion}

The Ti element has a guiding significance for discussing the formation tectonics environment of magmatism. Through the research on Mesozoic liparite and basalt at the Greater Xing' an Mountain Range, Lin et al. [19] (2000) believed that the geochemical properties of low-Ti liparite are similar to that of liparite related to the basaltic magma differentiation, high-Ti liparite and alkali basalt have bimodal geochemical characteristics, similar to the combination of basalt and alkali liparite of African Kenya rift valley, being partial melting of continental crust induced by continental flood basalt. High-Ti liparite inherits the geochemical feature that alkali series of 


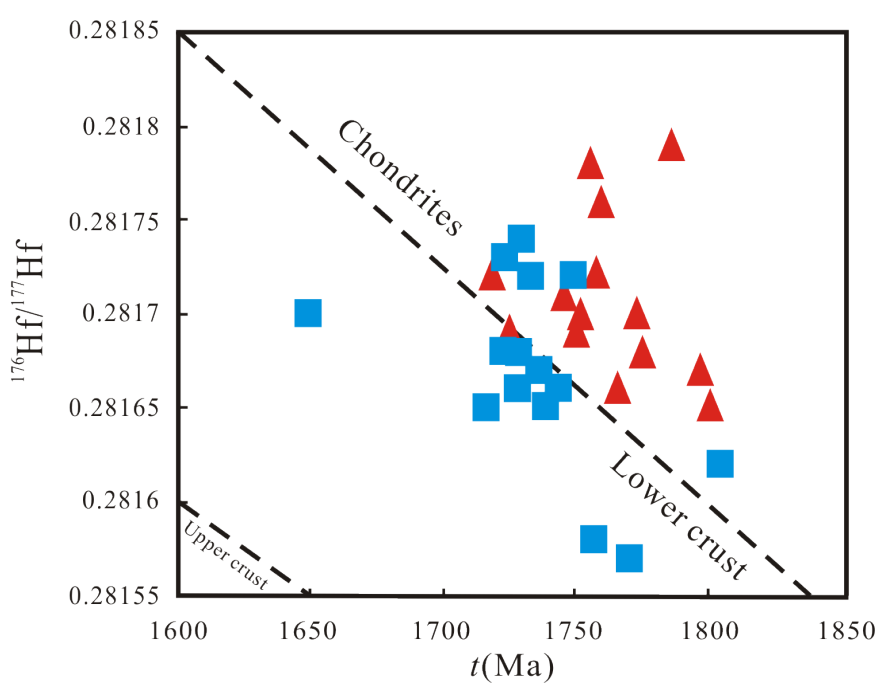

(a)

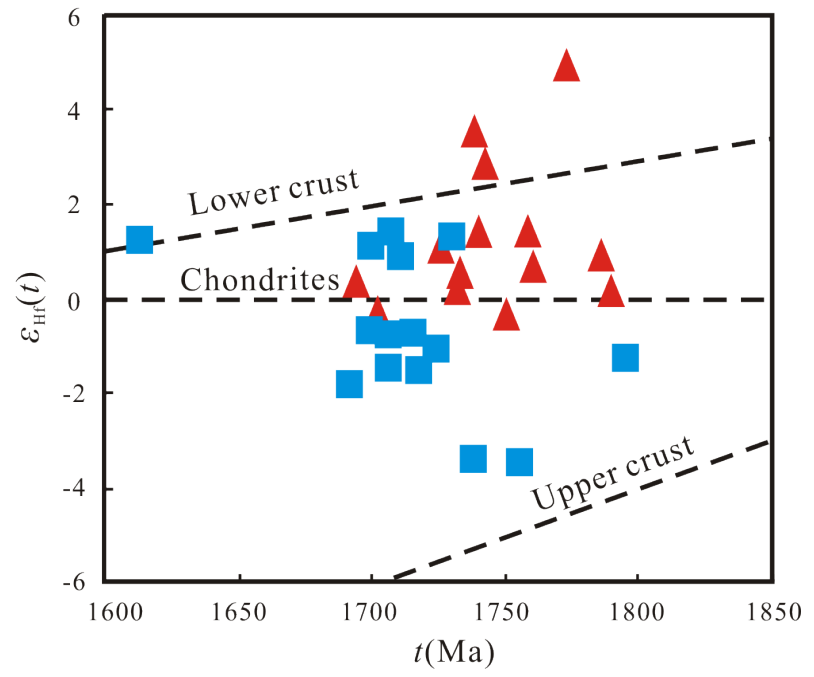

(b)

Figure 8. Hf isotopic composition and temporal variations of Hai Zi bimodal intrusive rocks Diabase-Blue Round; Granite porphyryRed Triangle.

Table 3. Zircons Hf isotopic compositions of the Hai Zi Bimodal Intrusive rocks.

\begin{tabular}{|c|c|c|c|c|c|c|c|c|c|c|c|c|}
\hline Samples & Age(Ma) & ${ }^{176} \mathrm{Hf} /{ }^{177} \mathrm{Hf}$ & $2 \delta$ & ${ }^{176} \mathrm{Yb} /{ }^{177} \mathrm{Hf}$ & $2 \delta$ & ${ }^{176} \mathrm{Lu} /{ }^{177} \mathrm{Hf}$ & $2 \delta$ & $\left({ }^{176} \mathrm{Hf} /{ }^{177} \mathrm{Hf}\right)_{\mathrm{t}}$ & $\varepsilon_{\mathrm{Hf}}(t)$ & $t_{\mathrm{DM}}(\mathrm{Ma})$ & $t_{\mathrm{DM}}^{\mathrm{c}}(\mathrm{Ma})$ & $f_{\mathrm{Lu} / \mathrm{Hf}}$ \\
\hline D1205-1 & 1702 & 0.281732 & 0.000025 & 0.069086 & 0.001512 & 0.001238 & 0.000028 & 0.281692 & -0.2 & 2144 & 2404 & \\
\hline D1205-3 & 1740 & 0.281752 & 0.000024 & 0.060452 & 0.001107 & 0.001092 & 0.000016 & 0.281716 & 1.429401 & 2108 & 2327 & -0.96709 \\
\hline D1205-5 & 1758 & 0.281745 & 0.000022 & 0.069122 & 0.000597 & 0.001212 & 0.000009 & 0.281704 & 1.427523 & 2125 & 2341 & -0.963502 \\
\hline D1205-7 & 1726 & 0.281758 & 0.000024 & 0.07 & 0.003988 & 0.00 & 0.000062 & 0.28 & 1.05 & 2114 & 2340 & -0.95970 \\
\hline D1205-9 & 1773 & 0.281812 & 0.000023 & 0.027713 & 0.000307 & 0.000578 & 0.000004 & 0.281793 & 4.912392 & 1998 & 2137 & -0.982601 \\
\hline D1205-11 & 1738 & 0.281836 & 0.000029 & 0.115399 & 0.00 & 0.001831 & 0.000087 & 0.281776 & 3.517257 & 2031 & 2196 & -0.9 \\
\hline D1205-13 & 1732 & 0.281724 & 0.000023 & 0.061597 & 0.000516 & 0.001165 & 0.000004 & 0.281686 & 0.173489 & 1 & 2399 & -0.96491 \\
\hline D1205-15 & 1742 & 343 & 0.00003 & 0.15 & 0.007177 & 0.002664 & 0.000131 & 755 & 2.8 & 2008 & 2240 & -0.919757 \\
\hline D1438-2 & 1707 & 0.281785 & 0.000023 & 0.068143 & 0.000658 & 0.00148 & 0.000009 & 0.281737 & 1.428925 & 2084 & 2302 & -0.955408 \\
\hline D1438-4 & 1724 & 0.281712 & 0.000023 & 0.082533 & 0.00088 & 0.001683 & 0.00006 & 0.281656 & -1.049525 & 2199 & 2469 & -0.949298 \\
\hline D1438-6 & 1699 & 0.281763 & 0.000029 & 0.135511 & 0.000461 & 0.002477 & 0.000015 & 0.2 & -0.65968 & 2172 & 2425 & -0.92539 \\
\hline D1438-10 & 1700 & 0.28175 & 0.000027 & 0.028876 & 0.000211 & 0.000563 & 0.000004 & 0.281732 & 1.098437 & 2082 & 2317 & -0.983038 \\
\hline D1438-12 & 1711 & 0.281756 & 0.00002 & 0.053526 & 0.000756 & 0.001133 & 0.000007 & 0.281719 & 0.877603 & 21 & 2339 & -0.965875 \\
\hline D1438-14 & 1739 & 0.281639 & 0.000034 & 0.068724 & 0.00162 & 0.001771 & 0.000056 & 0.281581 & -3.397965 & 2305 & 2625 & -0.94665 \\
\hline D1438-16 & 1730 & 0.281744 & 0.000029 & 0.038022 & 0.000685 & 0.000769 & 0.000011 & 0.281719 & 1.308678 & 2101 & 2327 & -0.976823 \\
\hline D1438-18 & 1718 & 0.28167 & 0.00002 & 0.03103 & 0.00069 & 0.00067 & 0.00003 & 0.281647 & -1.53797 & 2200 & 2494 & -0.979825 \\
\hline D1438-20 & 1613 & 0.28176 & 0.00002 & 0.00181 & 0.00004 & 0.08328 & 0.00062 & 0.2817 & 1.252 & 2144 & 2357 & -0.94547 \\
\hline
\end{tabular}

$\mathrm{Hf}_{(t)}=10000 \times\left\{\left[\left({ }^{176} \mathrm{Hf} /{ }^{177} \mathrm{Hf}\right)_{\mathrm{s}}-\left({ }^{176} \mathrm{Lu} /{ }^{177} \mathrm{Hf}\right)_{\mathrm{S}} \times\left(\mathrm{e}^{\lambda t}-1\right)\right] /\left[\left({ }^{176} \mathrm{Hf} /{ }^{177} \mathrm{Hf}\right)_{\mathrm{CHUR}, 0}-\left({ }^{176} \mathrm{Lu} /{ }^{177} \mathrm{Hf}\right)_{\mathrm{CHUR}} \times\left(\mathrm{e}^{\lambda t}-1\right)\right]-1\right\} . t_{\mathrm{DM}}=1 / \lambda \times \ln \left\{1+\left[\left({ }^{176} \mathrm{Hf} /{ }^{177} \mathrm{Hf}\right)_{\mathrm{S}}-\right.\right.$ $\left.\left.\left({ }^{176} \mathrm{Hf} /{ }^{177} \mathrm{Hf}\right)_{\mathrm{DM}}\right] /\left[\left({ }^{176} \mathrm{Lu} /{ }^{177} \mathrm{Hf}\right)_{\mathrm{S}}-\left({ }^{176} \mathrm{Lu} /{ }^{177} \mathrm{Hf}\right)_{\mathrm{DM}}\right]\right\} . t_{\mathrm{DM}}{ }^{\mathrm{C}}=t_{\mathrm{DM}}-\left(t_{\mathrm{DM}}-t\right) \times\left[\left(f_{\mathrm{CC}}-f_{\mathrm{s}}\right) /\left(f_{\mathrm{cc}}-f_{\mathrm{DM}}\right)\right] . f_{\mathrm{Lu} / \mathrm{Hf}}=\left({ }^{176} \mathrm{Lu} /{ }^{177} \mathrm{Hf}\right)_{\mathrm{S}} /\left({ }^{176} \mathrm{Lu} /{ }^{177} \mathrm{Hf}\right) \mathrm{CHUR}-1 . \lambda=1.867 \times$ $10^{-11} / \mathrm{a} ;\left({ }^{176} \mathrm{Lu} /{ }^{177} \mathrm{Hf}\right)_{\mathrm{S}}$ and $\left({ }^{176} \mathrm{Hf} /{ }^{177} \mathrm{Hf}\right)_{\mathrm{S}}$ are Sample measurement values; $\left({ }^{176} \mathrm{Lu} /{ }^{177} \mathrm{Hf}\right){ }_{\mathrm{CHUR}}=0.0332,\left({ }^{176} \mathrm{Hf} /{ }^{177} \mathrm{Hf}\right)_{\mathrm{CHUR}, 0}=0.282772 ;\left({ }^{176} \mathrm{Lu} /{ }^{177} \mathrm{Hf}\right){ }_{\mathrm{DM}}=0.0384$, $\left({ }^{176} \mathrm{Hf} /{ }^{177} \mathrm{Hf}\right)_{\mathrm{DM}}=0.28325 ;\left({ }^{176} \mathrm{Lu} /{ }^{177} \mathrm{Hf}\right)_{\text {Average crustal }}=0.015 ; f_{\mathrm{cc}}=\left[\left({ }^{176} \mathrm{Lu} /{ }^{177} \mathrm{Hf}\right)_{\text {Average crustal }} /\left({ }^{176} \mathrm{Lu} /{ }^{177} \mathrm{Hf}\right) \mathrm{CHUR}\right]-1 ; f_{\mathrm{s}}=f_{\mathrm{Lu} / \mathrm{Hf}} ; f_{\mathrm{DM}}=\left[\left({ }^{176} \mathrm{Lu} /{ }^{177} \mathrm{Hf}\right)_{\mathrm{DM}} /\left({ }^{176} \mathrm{Lu} /{ }^{177} \mathrm{Hf}\right)\right.$ CHUR] $-1 ; t$ is the crystallization age of Zircon. 
basalt is depleted in high field intensity elements [20]-[22].

In this area, the Ti element of Mesozoic Haizi granite porphyry shows depletion signs, its $\mathrm{TiO}_{2}$ is low in content, so it belongs to low-Ti calc-alkaline granite; according to its $\mathrm{Hf}$ isotope characteristics and the elements enrichment and depletion patterns shown one minor elements spider diagram, it's inferred that the Haizi granite porphyry should belong to intercontinental liparite related to basaltic magma differentiation, namely some lithogenous material of the Haizi granite porphyry may directly come from diabase.

Due to their small contents, the minor elements can sensitively and accurately reflect geochemical activities in the geological history period. Some minor elements have stable properties and therefore may not easily be contaminated by lithosphere components and consequently can reflect the initial tectonics of rock formation. Hence, in this paper, the relatively stable minor elements $\mathrm{Zr}, \mathrm{Y}$ and $\mathrm{Nb}$ in the Haizi bimodal intrusive rock were chosen for studying the tectonics environment of diabase; the major and minor elements were chosen for studying the tectonics environment of granite porphyry.

In the 2Nb-Zr/4-Y illustration (Figure 9(a)), the Haizi diabase completely falls into the A1 + A2 area, namely inboard rift valley basalt area; in the $\mathrm{Zr}-\mathrm{Zr} / \mathrm{Y}$ illustration (Figure 9(b)), the projection point also completely falls into the same area. The two tectonics illustrations indicate that the Haizi diabase comes into being in the inboard
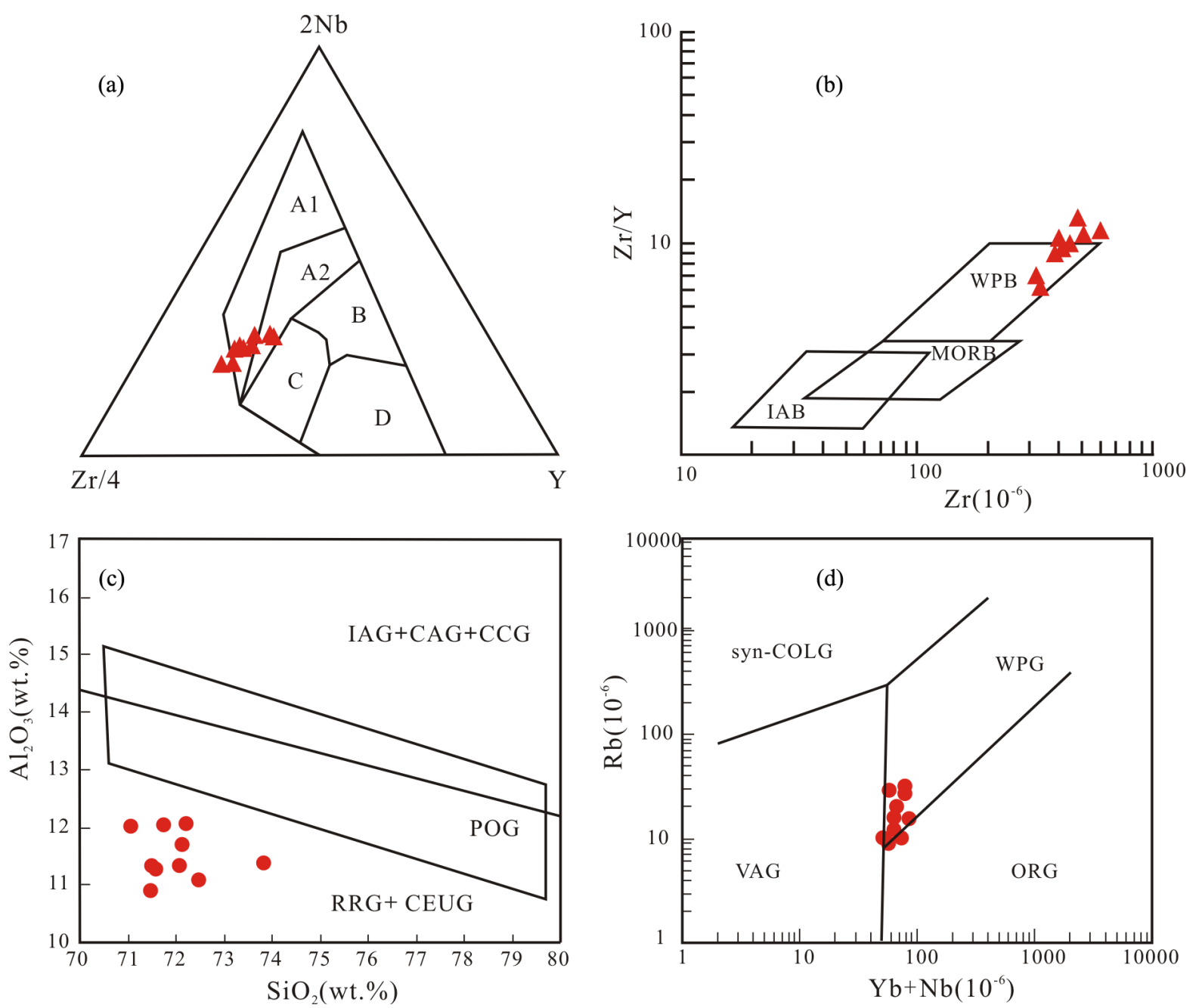

Figure 9. Discrimination diagrams of tectonic setting for Hai Zi bimodal intrusive rocks Diabase-Red Triangle; Granite porphyry-Red Triangle; (a) A1 + A2-Interpolate basalts; A2 + C-Interpolate tholeiitic; B-P type MORB; D-N type MORB; C + D-Volcanic arc basalts; (b) WPB-“Within-plate” basalts; MORB-Mid Ocean ridge basalt; IAB-Island arc Tholeiitic [18]; (c) IAG-Island arc granitoids; CAG-Continental arc granitites; CCG-Continental collision granitoids; POG-Post-organic granitoids; RRG-Rift-related granitoids; CEUG-Continent epeirogenic uplift granitites; D-Volcanic arc granites; ORG-Ocean ridge Granite; WPG-“Within-plate” granite; Syn-COLG-Syn-collisionalgranite. 
rift valley environment. In the $\mathrm{SiO}_{2}-\mathrm{Al}_{2} \mathrm{O}_{3}$ illustration (Figure 9(c)), the projection point of the Haizi granite porphyry completely falls into the RRG+ CEUG area, indicating that it is a granite related to rift valley; in the $\mathrm{Yb}+\mathrm{Nb}-\mathrm{Nb}$ illustration (Figure 9(d)), the projection point of the Haizi granite porphyry falls into the WPG area, it can be inferred that it formed in the inboard extension environment.

It was believed that Kunyang rift valley initially tensed at 1.8 - $1.6 \mathrm{Ga}$ [23]-[25], the time is corresponding to the supercontinent Columbia breakup (at about $1.7 \mathrm{Ga}$ ) occurred at the end of the Proterozoic eon throughout the world. Consequently, the Kunyang rift valley tension event is possibly not the sole tectonics event, its breakup is intimately closed with the supercontinent Columbia breakup and possibly a component of that breakup [26]-[30]. Of the discovered bimodal intrusive rock mass this time, the granite porphyry age is $1764 \pm 18 \mathrm{Ma}$, the diabase age is $1765 \pm 6 \mathrm{Ma}$, being the first Paleoproterozoic magmatism discovered in the central Yunnan area [31]-[35], which end the history of the southwestern margin of the Yangtze platform lacking $1.7 \mathrm{Ga}$ magmatism and can serve as important reference for investigating the relationship between the breakup of the Kunyang rift valley and the supercontinent Columbia breakup [36] [37].

\section{Conclusions}

1) The LA-ICP-MS zircon U-Pb dating shows that the ${ }^{207} \mathrm{~Pb} /{ }^{206} \mathrm{~Pb}$ weighted average ages of diabase and granite porphyry in central Yunnan are respectively $1764 \pm 18 \mathrm{Ma}$ and $1765 \pm 5.4 \mathrm{Ma}$; excluding the experimental errors, we believe that they are bimodal intrusive rock masses of the same era.

2) The Haizi basal and acidic rock combination reflects the bimodal magmatism movement characteristics of continental rift valley and is also the first $1.7 \mathrm{Ga}$ bimodal intrusive rock discovered in the southwestern margin of the Yangtze platform;

3) The chemical analysis shows that the Haizi diabase belongs to high-potassium alkaline basalt series; the granite porphyry belongs to low-potassium liparite series; the HF isotope analysis shows that some lithogenous material of the granite porphyry of the bimodal intrusive rock comes from the diabase and a product of rapid upsurge of mantle substance; the whole bimodal rock body came into being in inboard rift valley tectonics environment and belongs to the product of the Kunyang rift valley breakup period (16 - $1.8 \mathrm{Ga})$, corresponding to the time of the global supercontinent Columbia breakup and therefore significant for researches.

\section{References}

[1] Li, Z.X., Zhang, L., Christopher, M.A., et al. (1995) South China in Rodinia-Part of the Missing Link between Australia-East Antarctica and Laurentia? Geology, 23, 407-410.

[2] Fitzsimons (1992) Grenville-Age Basement Provinces in East Antarctica-Evidence for Three Separate Collisional Origins. Geology, 28, 879-882.

[3] Li, Z.X., Li, X.H., Zhou, H.W., et al. (2002) Grenvillian Continental Collision in South China-New SHRIMP U-Pb Zircon Results and Implication for the Configuration of Rodinia. Geology, 30, 163-166.

[4] Yan, D.P., Zhou, M.F., Song, H.L., et al. (2002) Where Was South China Located in the Reconstruction of Rodinia? Earth Science Frontiers, 9, 249-256.

[5] Wang, H.J., Li, J.C. and Xue, J.Y. (2009) Response of Proterozoic Mineralization on the Kangdian Axis to the Rodinia Breakup. Acta Geological Sichuan, 29, 11-15.

[6] Zhao, G.C., Cawood, P.A., Wilde, S.A. and Sun, M. (2002) Review of Global 2.1 - 1.8 Ga Origins: Implications for a Pre-Rodinia Supercontinent. Earth-Science Reviews, 59, 125-162. http://dx.doi.org/10.1016/S0012-8252(02)00073-9

[7] Luo, Y.N. (1985) Contribution to Pan Zhihua-Xi Chang Rift Zone, China. In: Zhang, Y.X. and Liu, B.G., Eds., Pan-Xi Rift Anthology in China, Geological Publishing House, Beijing, 1-25. (In Chinese)

[8] Hua, R.M. (1990) On the Kunyang Aulacogen. Acta Geological Sinica, 64, 23-27. (In Chinese)

[9] Gong, L., He, Y.T., Cheng, T.Y., et al. (1996) Kunyang Ancient Rift Type Copper Deposit, Dongchuan, Yunna. Metallurgical Industry Press, Beijing, 62-68. (In Chinese)

[10] Hou, K.J., Li, Y.H. and Tian, Y.R. (2009) In Situ U-Pb Zircon Dating Using Laser Ablation-Multi Ion Counting-ICPMS. Mineral Deposits, 28, 481-492.

[11] Wang, Z.Z., Guo, Y., Yang, B., Wang, S.W., Sun, X.M., Hou, L., et al. (2013) Discovery of the 1.73Ga Haizi Anorogenic Type Granite in the Western Margin of Yangtze Craton, and Its Geological Significance. Acta Geologica Sinica, 87, 931-942.

[12] Middlemost, E.A.K. (1985) Magmas and Magmatic Rocks. Longman, London, 1-266. 
[13] Peccerillo, A. and Taylor, S.R. (1976) Geochemistry of Eocene Calc-Alkaline Volcanic Rocks from the Kastamonu Area, Northern Turkey. Contributions to Mineralogy and Petrology, 58, 63-81. http://dx.doi.org/10.1007/BF00384745

[14] Sun, S. and MacDonough, W.F. (1989) Chemical and Isotopic Systematics of Oceanic Basalts: Implications for Mantle Composition and Processes. Geological Society London, Special Publications, 42, 313-345.

[15] Pearce, J.A., Harris, N.B.W. and Tindle, A.G. (1984) Trace Element Discrimination Diagrams for the Tectonic Interpretation of Granitic Rocks. Journal of Petrology, 25, 956-983. http://dx.doi.org/10.1093/petrology/25.4.956

[16] Deng, J.F. (1996) Continental Roots-Plume Tectonics of China: Key to the Continental Dynamics. Geological Publishing House, Beijing, 49-52.

[17] Wu, F.Y., Li, X.H., Zheng, Y.F. and Gao, S. (2007) Lu-Hf Isotopic Systematics and Their Applications in Petrology. Acta Petrologica Sinica, 23, 185-220.

[18] Pearce, J.A. and Norry, M.J. (1979) Petrogenetic Implications of Ti, Zr, Y, and Nb Variations in Intrusive Rocks. Contributions to Mineralogy and Petrology, 69, 33-47. http://dx.doi.org/10.1007/BF00375192

[19] Lin, Q., Ge, W.S., Sun, Y.D., Wu, F.Y., Chongkwan, W., Emoonwon, L., et al. (2000) Genetic Relationships between Two Types of Mesozoic Rhyolites and Basalts in Great Xing'an Ridge. Journal of Changchun University of Science and Technology, 30, 322-328.

[20] Macdonald, R., Davies, G.R., Bliss, C.M., Leat, P.T., Bailey, D.K. and Smith, R.L. (1987) Geochemistry of High-Silica Peralkaline Rhyolites, Naivasha, Kenya Rift Valley. Journal of Petrology, 28, 979-1008. http://dx.doi.org/10.1093/petrology/28.6.979

[21] Davies, G.R. and Macdonald, R. (1987) Crustal Influences in the Petrogenesis of the Naivasha Basalt-Cementite Complex: Combined Trace Element and Sr-Nd-Pb Isotope Constraints. Journal of Petrology, 28, 1009-1031. http://dx.doi.org/10.1093/petrology/28.6.1009

[22] Black, S., Macdonald, R. and Kelly, M.R. (1997) Crustal Origin for Peralkaline Rhyolites from Kenya: Evidence from U-Series Disequilibria and Th-Isotopes. Journal of Petrology, 38, 277-297. http://dx.doi.org/10.1093/petroj/38.2.277

[23] Chang, X.Y., Zhu, B.Q., Sun, D.Z., Qiu, H.N. and Zou, R. (1997) Isotope Geochemistry Study of Dongchuan Copper Deposits in Middle Yunnan Province, SW China: Stratigraphic Chronology and Application of Geochemical Exploration by Lead Isotopes. Geochimica, 26, 32-38.

[24] Zhao, X.F., Zhou, M.F., Li, J.W., Sun, M., Gao, J.F., Sun, W.H. and Yang, J.H. (2010) Late Paleoproterozoic to Early Mesoproterozoic Dongchuan Group in Yunnan, SW China: Implications for Tectonic Evolution of the Yangtze Block. Precambrian Research, 182, 57-69. http://dx.doi.org/10.1016/j.precamres.2010.06.021

[25] Wang, S.W., Liao, Z.W., Yu, Y.S., et al. (2011) Western Margin of the Yangtze Basement Mineralization and Prospecting Direction. Chengdu Center, China Geological Survey, Chengdu.

[26] Bacon, C.R. and Druitt, T.H. (1988) Compositional Evolution of the Zoned Calcalkaline Magma Chamber of Mount Mazama, Crater Lake, Oregon. Contributions to Mineralogy and Petrology, 98, 224-256. http://dx.doi.org/10.1007/BF00402114

[27] Cull, J.P., O’Reilly, S.Y. and Griffin, W.L. (1991) Xenolith Geotherms and Crustal Models in Eastern Australia. Tectonophysics, 192, 359-366. http://dx.doi.org/10.1016/0040-1951(91)90109-6

[28] Condie, K.C. (2002) Breakup of a Paleoproterozoic Supercontinent. Gondwana Research, 5, 41-43. http://dx.doi.org/10.1016/S1342-937X(05)70886-8

[29] Christiansen, E.H., Haapala, I. and Hart, G.L. (2007) Are Cenozoic Topaz Rhyolites the Erupted Equivalents of Proterozoic Rapakivi Granites? Examples from the Western United States and Finland. Lithos, 97, 219-246. http://dx.doi.org/10.1016/j.lithos.2007.01.010

[30] Doe, T. and Remer, J. (1982) Analysis of Constant-Head Well Tests in Nonporous Fractured Rock. Journal of Petrology, 18, 104-141.

[31] Ernst, R.E., Wingate, M.T.D., Buchan, K.L., et al. (2008) Global Record of 1600 - 700 Ma Large Igneous Provinces (LIPs): Implications for the Reconstruction of the Proposed Nuna (Columbia) and Rodinia Supercontinents. Precambrian Research, 160, 159-178.

[32] Mahoney, J.J. (1997) Large Igneous Province: Continental, Oceanic, and Planetary Flood Volcanism. Geophysical Monograph 100, American Geophysical Union, Washington DC, 297-333.

[33] Grove, T.L. and Kinzler, R.J. (1986) Petrogenesis of Andesites. Annual Review of Earth and Planetary Sciences, 14, 417-454.

[34] Geist, D., Howard, K.A. and Larson, P. (1995) The Generation of Oceanic Rhyolites by Cry Stalfractionation: The Basalt-Rhyolite Association at Volcano Alcedo, Galpagos Archipelago. Journal of Petrology, 8, 304-341. 
[35] Guo, Y., Wang, S.W., Sun, X.M., Wang, Z.Z., Yang, B., et al. (2014) The Paleoproterozoic Breakup Event in the Southwest Yangtze Block: Evidence from U-Pb Zircon Age and Geochemistry of Diabase in Wuding, Yunnan Province, SW China. Acta Geologica Sinica, 88, 1651-1665.

[36] Huppert, H.E. and Sparks, R.S.J. (1988) The Generation of Granitic Magmas by Intrusion of Basalt into Continental Crust. Journal of Petrology, 29, 599-624. http://dx.doi.org/10.1093/petrology/29.3.599

[37] Hildreth, W. (1981) Gradients in Silicic Magma Chambers: Implications for Lithospheric Magmatism. Journal of Geophysical Research: Solid Earth (1978-2012), 86, 10153-10192. 